\title{
PENGGUNAAN METODE DISKUSI KELOMPOK UNTUK MENINGKATKAN HASIL BELAJAR SISWA MATERI BIOTIK DAN ABIOTIK DI KELAS VII - 1 MTs NEGERI LANGSA
}

\author{
Oleh : Dra. Z A I M A H*
}

\begin{abstract}
Abstrak
Performance siswa yang produktif, berprestasi dan mandiri sebagai salah satu indikasi penting dalam mutu pembelajaran dapat dilihat dari hasil kegiatan belajarnya. Hal ini terkait pula dengan tingkat pemahaman siswa karena tinggi rendahnya prestasi belajar siswa juga hasil dari upaya belajarnya. Rendahnya perolehan prestasi belajar IPA di MTs Negeri Langsa menunjukkan adanya indikasi terhadap rendahnya kinerja belajar siswa dan kemampuan guru dalam mengelola pembelajaran yang berkualitas. Tujuan penelitian ini adalah untuk mengetahui peningkatan pemahaman siswa pada materi biotik dan abiotik dengan metode diskusi kelompok di kelas VII-1. Di samping itu melalui penelitian ini siswa terlatih untuk dapat memecahkan masalah. Bagi guru penelitian ini diharapkan dapat meningkatkan kemampuan profesional dan pembelajaran dengan metode diskusi kelompok menjadi alternatif pembelajaran untuk meningkatkan prestasi siswa. Pendekatan yang digunakan adalah pendekatan kualitatif karena penelitian ini mengkaji lebih mendalam penggunaan metode diskusi kelompok. Dalam pembelajaran IPA yang membantu siswa mengetahui, memahami, mengamalkan dalam kehidupan dunia nyata dan ingin mengetahui hasil belajar siswa setelah penggunaan metode diskusi kelompok tersebut. Berdasarkan analisis dan refleksi hasil tes prasyarat siklus I dan II dapat disimpulkan bahwa prestasi belajar siswa pada mata pelajaran IPA di MTs Negeri Langsa pada kondisi awal mencapai nilai 2,9 \% termasuk kualifikasi rendah dan pada siklus I dengan menggunakan metode diskusi mencapai nilai 29,41 \% maka angka tersebut kualifikasi sedang. Pada siklus II mencapai nilai 97,1\% maka angka tersebut kualifikasi tinggi. Berarti setelah siklus II semua subjek mengalami peningkatan prestasi belajar dengan menggunakan metode diskusi kelompok.
\end{abstract}

Kata Kunci : Hasil Belajar, Metode Diskusi Kelompok

\footnotetext{
* Penulis adalah Guru Madrasah Tsanawiyah Negeri 1 Langsa
} 


\section{A. PENDAHULUAN}

Sampai saat ini pelajaran IPA di MTs Negeri Langsa masih dianggap sebagai pelajaran yang amat sulit untuk dipelajari, sehingga hasil yang diperoleh siswa masih sangat jauh dari yang diharapkan. Sebagai gambaran dari hasil ulangan harian materi sebelumnya siswa yang memperolah nilai di bawah standar ketuntasan yang telah di tetapkan oleh pihak sekolah, hampir rata-rata nilai yang di peroleh siswa pada materi Biotik dan Abiotik masih sangat rendah dari KKM yang telah di tetapkan oleh pihak sekolah, rata-rata hasil belajar siswa adalah $\geq$ 40,13 .

Penyebab kesulitan belajar yang dihadapi siswa sangatlah komplek, yang salah satunya disebabkan oleh guru misalnya, guru dalam proses pembelajaran tidak mengikutsertakan siswa dalam pembelajaran secara aktif, siswa hanya disuruh menghafal, menerima konsep-konsep yang ada tidak melakukan sendiri. Sehingga hasilnya kurang bermakna dan tidak terekam dengan baik pada otak siswa.

Untuk meningkatkan hasil belajar siswa tersebut peneliti penerapan pembelajaran mengunakan diskusi kelompok. Pemilihan metode pembelajaran dengan menggunakan diskusi kelompok diharapkan bisa meningkatkan hasil belajar siswa dalam pelajaran IPA.

Oleh karena itu peneliti mengajukan penelitian dengan judul "Penggunaan metode diskusi kelompok untuk meningkatkan hasil belajar siswa materi biotik dan abiotik di kelas VII - 1 MTs Negeri Langsa semester genap Tahun Ajaran $2014 / 2015$.

\section{B. Hakikat Belajar} 3 jenis :

Hakikat belajar mengajar: menurut Abu Ahmadi, hakikat mengajar itu ada

1. Menanamkan pengetahuan kepada anak,

2. Menyampaikan pengetahuan dan kebudayaan kepada anak,

3. Suatu aktivitas mengatur lingkungan sebaik-baiknya dan menghubungkan dengan anak didik sehingga terjadi proses belajar. ${ }^{1}$

Hakikat belajar adalah usaha sadar untuk menguasai ilmu, untuk dapat menerapkan pengetahuan, untuk dapat melaksanakan suatu pekerjaan dengan baik. Jadi belajar dan mengajar saling berkaitan dalam suatu proses menuju perubahan pengetahuan, perubahan tingakah laku, perubahan keterampilan dan dapat mengatasi persoalan hidup dengan baik dan mandiri.

\section{Pengertian Hasil Belajar}

Untuk mengetahui sejauh mana proses belajar mengajar mencapai tujuan pembelajaran yang diharapkan, maka perlu diadakan tes hasil belajar. Menurut pendapat WinataPutra $(1997)^{2}$ tes hasil belajar adalah salah satu alat ukur yang

\footnotetext{
${ }^{1}$ Ahmadi, Abu dan Joko Tri Prasetya. 2006. Strategi Belajar Mengajar. Penerbit Setia, Bandung. Hal. 32

2 Winataputra, Udin, S, dkk. 2007. Teori Belajar dan Pembelajaran. Jakarta. Universitas Terbuka. Hal. 191
} 
paling banyak digunakan untuk menentukan keberhasilan seseorang dalam suatu proses belajar mengajar atau untuk menentukan keberhasilan suatu program pendidikan. Adapun dasar-dasar penyususan tes hasil belajar adalah sebagai berikut:

1. Tes hasil belajar harus dapat mengukur apa-apa yang dipelajari dalam proses pembelajaran sesuai dengan tujuan instruksional yang tercantum dalam kurikulum yang berlaku.

2. Tes hasil belajar disusun sedemikian sehingga benar-benar mewakili bahan yang telah dipelajari.

3. Bentuk pertanyaan tes hasil belajar hendaknya disesuaikan dengan aspek-aspek tingkat belajar yang diharapkan.

4. Tes hasil belajar hendaknya dapat digunakan untuk memperbaiki proses belajar mengajar.

A. Tabrani $(1992)^{3}$ mengatakan bahwa belajar mengajar adalah suatu proses yang rumit karena tidak sekedar menyerap informasi dari guru, tetapi melibatkan berbagai kegiatan maupun tindakan yang harus dilakukan, terutama bila diinginkan hasil yang lebih baik.

\section{Metode Pembelajaran}

Metode merupakan salah satu "sub-system" dalam "system pembelajaran", yang tidak bisa dilepaskan begitu saja. Metode adalah cara yang dianggap efisien yang digunakan oleh guru dalam menyampaikan suatu mata pelajaran tertentu kepada siswa-siswa agar tujuan yang telah dirumuskan sebelumnya dalam proses kegiatan pembelajaran dapat tercapai dengan efektif. Setiap mata pelajaran mempunyai metode tertentu sesuai dengan kekhususan mata pelajaran tersebut. Oleh sebab itu guru hendaknya dapat menentukan metode apa yang paling efisien bagi mata pelajarannya sehingga tujuan pengajaran tercapai secara maksimal dan efektif. Metode pembelajaran merupakan salah satu cara yang digunakan dalam mengajar. Penggunaan sebuah metode mengajar harus tepat, efisien dan efektif, sehingga siswa dapat menerima, memahami, menguasai, dan mengembangkan bahan pelajaran.

\section{E. Pengertian Pembelajaran Diskusi Kelompok}

Metode diskusi kelompok adalah suatu cara mengajar yang dicirikan oleh suatu keterikatan pada suatu topik atau pokok pernyataan atau problem dimana para peserta diskusi dengan jujur berusaha untuk mencapai atau memperoleh suatu keputusan atau pendapat yang disepakati bersama, yang merupakan salah satu bentuk pembelajaran yang menanut teori konstruktivisme. Menurut teori belajar konstruktivisme, dalam proses perolehan pengetahuan, siswa harus mengkonstruksi sendiri pengetahuan-pengetahuan itu melalui interaksi antara

${ }^{3}$ A. Tabrani Rusyan, dkk, Pendekatan dalam Proses Belajar Mengajar, (Bandung: Remaja Karya) Hal.3. 
siswa dengan siswa lain dan siswa dengan guru. Coob menyatakan bahwa "Tradisi konstruktivisme tidak hanya sebagai aktivitas individu tetapi sebagai interaksi satu dengan yang lain, berupa interaksi dalam kelas. Ketika siswa memperhatikan penyelesaian siswa lain dan berusaha menggunakannya, serta mempertanyakannya, maka kemampuan untuk merefleksi serta menyusun kembali pemahaman menjadi meningkat, akibatnya belajar menjadi bermakna.

Metode diskusi kelompok yang menekankan pada interaksi antara siswa dengan orang lain diskusi kelompok merupakan metode belajar dimana siswa belajar dalam kelompok kecil, saling membantu untuk memahami suatu bahan pembelajaran, memriksa dan memperbaiki jawaban teman, serta kegiatan lainnya dengan tujuan untuk mencapai prestasi belajar yang gemilang. Nur (1999) berpendapat bahwa :

Pembelajar diskusi kelompok yaitu pembelajaran yang melibatkan unsurunsur siswa itu sendiri, sehingga siswa dapatr berinteraksi dalam menyelesaikan tugas-tugas yang sulit. Pembelajaran diskusi kelompok merupakan cara proses belajar siswa yang dalam satu kelompok setiap individu saling membantu terhadap yang lain dalam kelompoknya sehingga tercapai tujuan bersama.

Berkaitan dengan hal tersebut Misbah (1992) berpendapat bahwa "Dalam pembelajaran diskusi kelompok terdiri dari 5 sampai 20 orang dengan jenis kelamin yang berbeda, tingkat kemampuan yang berbeda pula. Siswa dapat menerima informasi dengan cepat bila melakukan sendiri secara langsung".

Ada beberapa hal yang perlu dipenuhi dalam metode diskusi kelompok agar lebih menjamin para siswa belajar secara aktif. Hal tersebut meliputi :

1. Para siswa yang bergabung dalam suatu kelompok harus merasa bahwa mereka adalah bagian dari sebuah team yang mempunyai tujuan bersama yang harus dicapai.

2. Para siswa yang bergabung dalam suatu kelompok harus menyadari bahwa masalah yang mereka hadapi adalah masalah kelompok dan akan menjadi tanggung jawab bersama oleh seluruh anggota itu.

3. Untuk mencapai hal yang maksimum para siswa bergabung dalam kelompok itu harus berbicara satu sama lain dalam mendiskusikan masalah yang dihadapi bahwa setiap pekerjaan siswa mempunyai akibat langsung kepada keberhasilan kelompoknya.

Strategi ini merupakan strategi yang menarik untuk digunakan jika materi yang akan dipelajari dapat dibagi menjadi beberapa bagian dan materi tersebut tidak mengharuskan urutan penyampaian.

Kelebihan strategi ini adalah dapat melibatkan seluruh peserta didik dalam belajar dan sekaligus mengajarkan kepada orang lain.

Langkah-langkah:

1. Bagi kelas menjadi 5 kelompok (masing-masing terdiri dari 6 orang) untuk lima bagian pelajaran yang berbeda, langsung untuk mendiskusikan dan menyelesaikannya tanpa harus menerangkan terlebih dahulu

2. Dari kelima kelompok dipecah kembali menjadi enam kelompok dengan anggota berbeda. 
3. Setiap anggota kelompok baru menerangkan hasilnya kepada anggota lain (dalam satu kelompok) secara berurutan sampai semua kebagian.

4. Berikan 5 soal berbeda dari lima bagian pelajaran untuk diselesaikan oleh grup baru.

5. Berikan jawaban yang benar oleh guru melalui OHP atau tunjuk untuk menerangkan hasil kerjanya di papan tulis.

\section{F. Kerangka Berfikir}

Penelitian tindakan kelas ini menggunakan rancangan penelitian tindakan yang dilaksanakan di kelas, sehingga disebut Penelitian Tindakan Kelas (PTK). Penelitian ini terdiri dari 2 siklus masing-masing siklus meliputi : perencanaan, tindakan, pengamatan dan refleksi. Secara Skematis uraian digambarkan kerangka pemikirannya sebagai berikut:

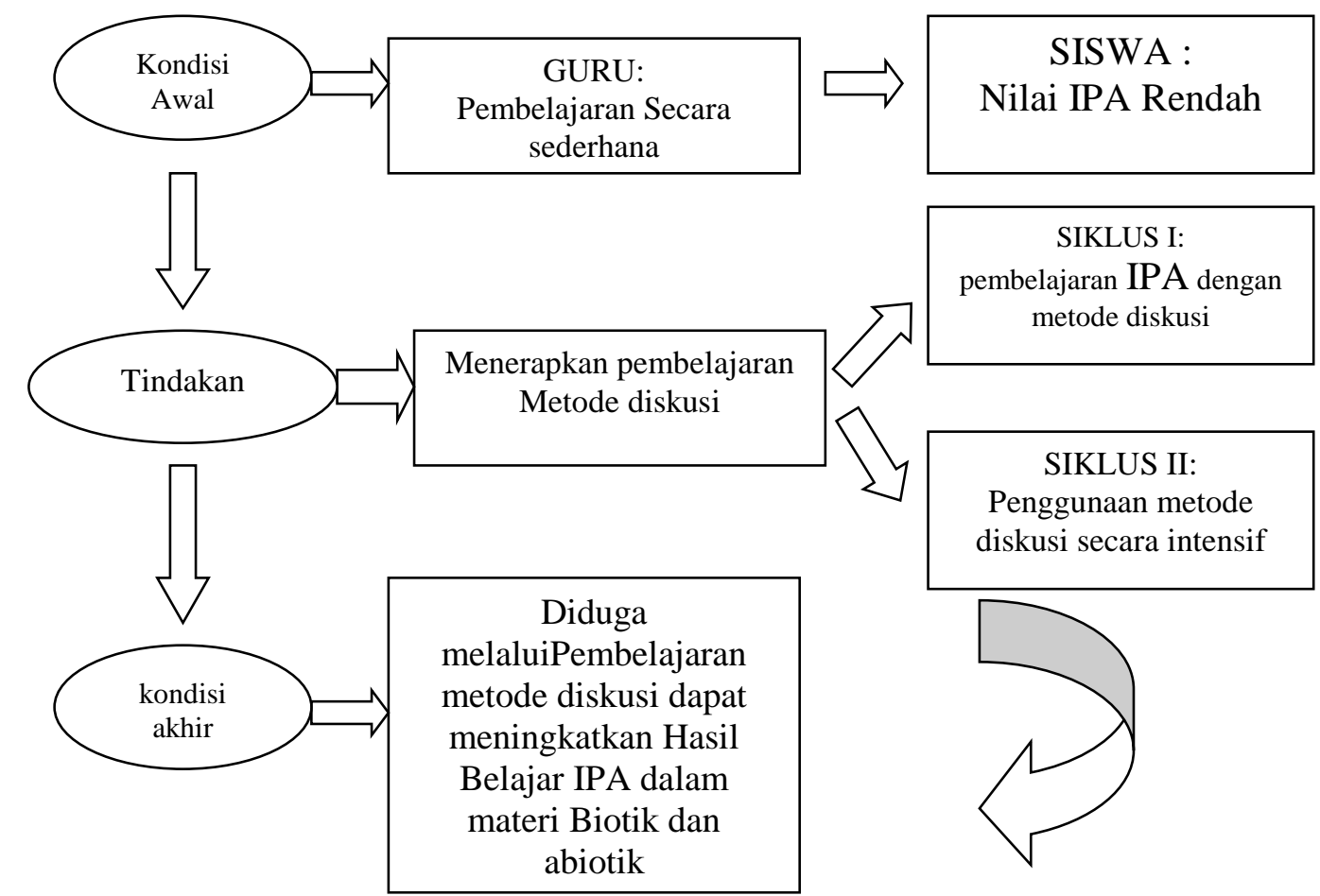

Gambar Diagram Alur Penelitian Tindakan Kelas

\section{G. METODE PENELITIAN}

\section{Setting Penelitian}

Penelitian ini akan dilaksanakan di kelas VII - 1 MTs Negeri Langsa Tahun Pelajaran 2014-2015, dengan alasan penulis merupakan guru aktif dan bertanggung jawab atas mata pelajaran IPA.

Penelitian ini dilaksanakan selama tiga bulan, mulai awal Pebruari s/d April Tahun ajaran 2014-2015 yaitu pada semester II. Penentuan waktu disesuaikan dengan hari efektif dikelas VII - 1 karena penelitian ini diadakan dalam 2 siklus, setiap siklus dua kali pertemuan. Pertemuan pertama pada siklus 1 
akan di lakukan pada tanggal 12 Pebruari 2015 dan pertemuan kedua di siklus I akan di laksanakan pada tanggal 22 Pebruari 2015, hasil siklus I pada pertemuan pertama dan kedua akan menjadi bahan masukan pada siklus II. Siklus II akan dilaksanakan dua kali pertemuan, pertemuan pertama akan di laksanakan pada tanggal 1 Maret 2015 dan pertemuan kedua siklus ke II akan dilaksanakan pada tanggal 11 Maret 2015. Subyek penelitian adalah siswa VII - 1, sejumlah 34 siswa. Dengan berbagai macam status sosial.

\section{Prosedur Penelitian}

Penelitian ini merupakan penelitian tindakan kelas (Action Recearch). Menurut Tim Pelatihan PGSM (1999) penelitian tindakan kelas didefinisikan sebagai suatu bentuk kajian yang bersifat reflektif oleh pelaku tindakan yang dilakukan untuk meningkatkan kemampuan rasional dari tindakan-tindakan mereka dalam melaksanakan tugas, memperdalam pemahaman terhadap tindakantindakan yang dilakukannya itu, serta memperbaiki kondisi di mana praktekpraktek pembelajaran tersebut dilakukan. Untuk mewujudkan tujuan-tujuan tersebut, penelitian tindakan kelas itu dilaksanakan berupa proses pengkajian berdaur (Cyclical) yang terdiri dari 4 tahap.

Adapun keempat tahapan pelaksanaan penelitian tindakan kelas adalah (Action Recearch) sebagai berikut:

a. Rencana : Tindakan apa yang akan dilakukan untuk memperbaiki, meningkatkan atau perubahan perilaku dan sikap sebagai solusi.

b. Tindakan : Apa yang dilakukan oleh guru atau peneliti sebagai upaya perbaikan, peningkatan atau perubahan yang diinginkan.

c. Observasi : Mengamati atas hasil atau dampak dari tindakan yang dilaksanakan atau dikenakan terhadap siswa.

d. Refleksi : Peneliti mengkaji, melihat dan mempertimbangkan atas hasil atau dampak dari tindakan dari berbagai kriteria.

Dari pendapat di atas, maka inti dari penelitian tindakan adalah adanya tindakan untuk meningkatkan atau memperbaiki kualitas pelaksanaan KBM yang lebih baik. Langkah-langkah pelaksanaan tindakan meliputi keempat komponen yang telah disebutkan di atas dan berlangsung secara siklus, yaitu rencanatindakan-observasi-refleksi dan seterusnya seperti pada gambar, sehingga tercapai tujuan yang diinginkan dengan tindakan yang paling efektif.

Kegiatan penelitian ini meliputi tiga tahap, yaitu perencanaan, pelaksanaan dan analisis data. Kegiatan yang dilakukan pada tahap perencanaan adalah menyusun/menyiapkan materi pelajaran, menyusun instrument data dan menyusun rencana pembelajaran.

\section{Indikator Kinerja}

Dalam penelitian ini yang akan dilihat indikator kinerjanya. Dan indikator yang diharapkan dalam penelitian tindakan kelas ini adalah:

a. Terjadi peningkatan hasil belajar siswa dan mencapai ketuntasan belajar $=$ 70.

b. Terjadi peningkatan aktivitas belajar siswa pada setiap siklus. 
c. Terjadi peningkatan pelaksanaan proses belajar mengajar yang diselenggarakan oleh guru

\section{Teknik dan Alat Pengumulan Data}

Dalam penelitian ini pengumpulan data menggunakan teknik tes dan non tes. Tes tertulis digunakan pada akhir siklus I dan siklus II. Teknik non tes meliputi teknik observasi dan dokumentasi. Observasi digunakan pada saat pelaksanaan penelitian tindakan kelas. Kemampuan memahami materi biotik dan abiotik pada siklus I dan II. Sedangkan Teknik Dokumentasi dikumpulkan dari hasil kerajinan siswa.

\section{H. Analisis Data}

Analisis data yang digunakan dalam penelitian ini adalah teknik analisis deskriptif yang meliputi :

1. Analisis deskriptif komparatif hasil belajar dengan cara membandingkan hasil belajar pada siklus I, II dan membandingkan hasil belajar dengan indikator pada siklus I dan II .

2. Analisis deskriptif kualitatif, hasil observasi dengan cara membandingkan hasil observasi dan refleksi pada siklus I dan II.

Menurut Milas (1992: 16) ${ }^{4}$ data yang sudah terkumpul dianalisis dengan mempedomani langkah-langkah analisis data penelitian kualitatif, analisis berlangsung dengan tiga jalur kegiatan yang terjadi secara bersamaan yaitu:

1. Reduksi data, yaitu meliputi proses penyeleksian, pemilihan, penyederhanaan dan pengkatagorian data, menganalisis dan penarikan kesimpulan.

2. Pengujian data, yaitu dengan mendeskripsikan apa yang terjadi

3. Penarikan kesimpulan yang dilakukan sejak tahap pengumpulan data dengan cara mencatat pada buku penelitian.

\section{HASIL PENELITIAN}

1. Deskripsi Kondisi Awal

Pembelajaran pada kondisi awal, dari 34 jumlah siswa kelas VII -1 MTs Negeri Langsa, hanya 1 siswa $(2,9 \%)$ yang tuntas, sedangkan sisanya sebanyak 33 siswa $(97,1 \%)$ tidak tuntas. Berdasarkan pada kegiatan kondisi awal, peneliti melakukan refleksi dari hasil kegiatan tersebut.

Pada kondisi awal didapatkan masih banyak siswa kurang aktif bahkan cenderung bosan. Proses pembelajaran tampak kaku karena siswa hanya melihat dan mendengar apa yang dijelaskan gurunya. Bertolak dari kondisi di atas, maka perlu adanya perubahan cara menyampaikan materi pelajaran. Untuk itulah maka peneliti menggunakan Metode Diskusi Kelompok untuk meningkatkan hasil belajar siswa.

4 Milas, 1992. Metodologi Penelitian Pendidikan. Surabaya: SIC (Surabaya Intellectual Club). Hal. 16 


\section{Hasil Penelitian Siklus I}

Berdasarkan hasil penelitian pada siklus I diperoleh nilai siswa yang berhasil tuntas sesuai dengan kriteria ketuntasan minimal (KKM 70), 10 siswa $(29,41 \%)$ tuntas, dan 24 siswa $(70,59 \%)$ tidak tuntas. Hal ini terjadi karena masih banyak siswa yang belum begitu memahami cara-cara melakukan kegiatan dengan menggunakan metode Diskusi Kelompok serta siswa masih enggan untuk bertanya kepada guru sehingga waktu banyak tidak efektif sesuai dengan apa yang direncanakan.

Berdasarkan hasil observasi peneliti dan pengamat atas hasil kemampuan siswa, maka peneliti dan pengamat kembali merencanakan untuk melanjutkan pada tindakan siklus II dengan terlebih dahulu melakukan perbaikan. Dengan demikian, maka direncanakan pada Siklus II ini penggunaan metode Diskusi Kelompok dilaksanakan lebih terarah lagi supaya hasil dicapai juga lebih optimal.

\section{Hasil Penelitian Siklus II}

Pada Siklus II, kemampuan siswa mengalami peningkatan, jumlah siswa yang tuntas meningkat yaitu sebanyak 33 siswa $(97,1 \%)$ sedangkan yang tidak tuntas hanya 1 siswa $(2,9 \%)$. Hasil tersebut mengindikasikan bahwa rasa takut salah dan malu untuk bertanya sudah berkurang. Siswa sudah mulai mau berbagi kepada teman-temannya. Bahkan mereka juga sudah berani mengajukan saran atau mengomentari pendapat temannya yang keliru. Kalau diperhatikan tiap aktivitas, memang peningkatannya tidak seberapa besar. Tetapi kalau dilihat dari pengelompokan partisipasi aktif dan pasif, prosentase tersebut cukup besar.Agar lebih jelas gambaran perbandingan peningkatan hasil kemampuan dari kondisi awal, Siklus I dan Siklus II, dapat dilihat dan diperhatikan pada rekapitulasi tabel dan grafik di bawah ini.

Tabel Rekapitulasi Ketuntasan Belajar Setiap Siklus

\begin{tabular}{|c|c|c|c|c|c|c|c|c|c|c|}
\hline \multirow[t]{2}{*}{ NO } & \multirow[t]{2}{*}{ KRITERIA } & \multicolumn{3}{|c|}{ KONDISI AWAL } & \multicolumn{3}{|c|}{ SIKLUS I } & \multicolumn{3}{|c|}{ SIKLUS II } \\
\hline & & JLH & KATEGORI & $\%$ & JLH & KATEGORI & $\%$ & JLH & KATEGORI & $\%$ \\
\hline 1 & NILAI $>70$ & 1 & $\mathrm{~T}$ & 2,9 & 10 & $\mathrm{~T}$ & 29,41 & 33 & $\mathrm{~T}$ & 97,1 \\
\hline 2 & NILAI $<70$ & 33 & TT & 97,1 & 24 & TT & 70,59 & 1 & TT & 2,9 \\
\hline & JUMLAH & 34 & & 100 & 34 & & 100 & 34 & & 100 \\
\hline
\end{tabular}

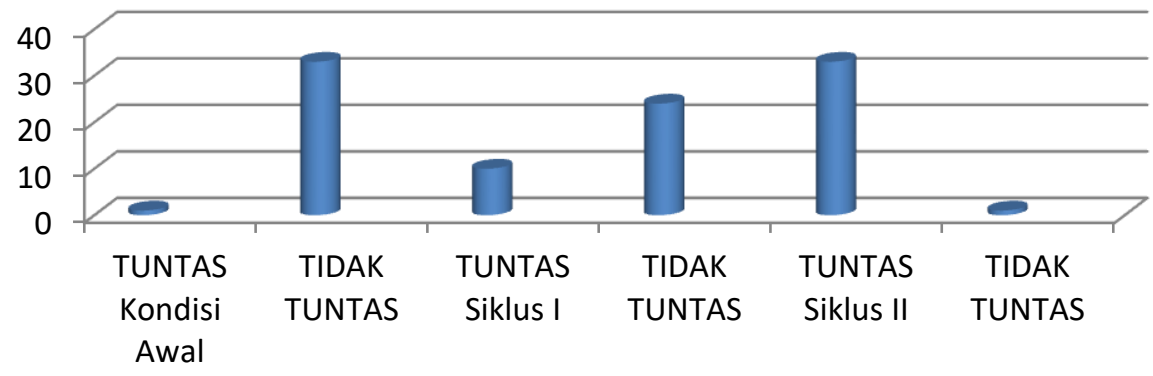


Berdasarkan data rekapitulasi perbandingan pada tabel dan grafik di atas, diketahui bahwa pada kondisi awal siswa kelas VII-1 yang tuntas hanya 1 siswa $(2,9 \%)$ yang tuntas, sedangkan sisanya sebanyak 33 siswa $(97,1 \%)$ tidak tuntas. Sedangkan pada Siklus I siswa yang tuntas mengalami peningkatan menjadi 10 siswa $(29,41 \%)$ tuntas, dan 24 siswa $(70,59 \%)$ tidak tuntas. Pada Siklus II kembali meningkat yaitu sebanyak 33 siswa $(97,1 \%)$ tuntas sedangkan yang tidak tuntas hanya 1 siswa $(2,9 \%)$. Disamping ketuntasan belajar, nilai rata-rata siswa juga meningkat pada setiap siklusnya, hal ini dapat dilihat pada rekapitulasi nilai tes siswa pada tabel dan grafik berikut :

Tabel Rekapitulasi Nilai Tes Setiap Siklus

\begin{tabular}{|l|c|c|c|}
\hline \multirow{2}{*}{ KETERANGAN } & \multicolumn{3}{|c|}{ NILAI } \\
\cline { 2 - 4 } & $\begin{array}{c}\text { KONDISI } \\
\text { AWAL }\end{array}$ & $\begin{array}{c}\text { SIKLUS } \\
\text { I }\end{array}$ & $\begin{array}{c}\text { SIKLUS } \\
\text { I }\end{array}$ \\
\hline NILAI TERTINGGI & 75 & 80 & 90 \\
\hline NILAI TERENDAH & 35 & 45 & 65 \\
\hline JUMLAH NILAI & 1870 & 2081 & 2910 \\
\hline NILAI RATA-RATA & 55,00 & 61,21 & 85,6 \\
\hline
\end{tabular}

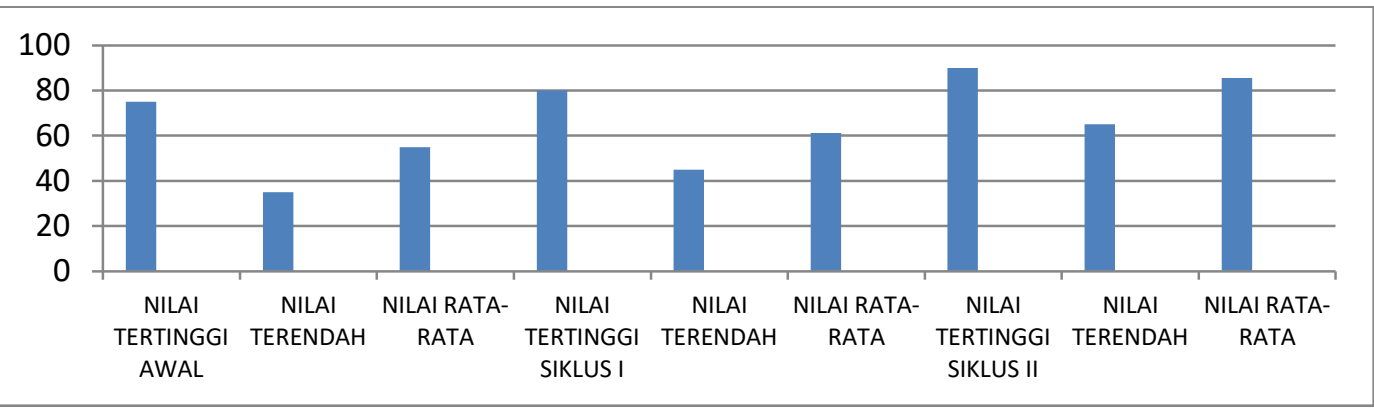

Gambar Grafik Rekapitulasi Nilai Tes Setiap Siklus

Data rekapitulasi perbandingan pada tabel dan grafik di atas menunjukkan bahwa pada kondisi awal nilai tertinggi hanya 75 dan nilai terendah 35 dengan nilai rata-rata hanya sebesar 55,00. Sedangkan pada Siklus I nilai tertinggi 80 dan nilai terendah 45 dengan nilai rata-rata mencapai 61,21. Pada Siklus II nilai tertinggi mencapai 90 sedangkan nilai terendah 65 dengan nilai rata-rata mencapai 85,6 .

\section{J. Kesimpulan}

Berdasarkan hasil penelitian dapat ditarik kesimpulan penerapan metode Diskusi Kelompok dapat meningkatkan hasil belajar siswa MTsN Langsa dalam materi biotik dan abiotik di kelas VII-1 semester genap tahun ajaran 2014/2015, peningkatan hasil belajar terjadi karena guru menggunakan metode Diskusi Kelompok dalam menyajikan materi biotik dan abiotik dalam penyusunan rencana pelaksanaan pembelajaran. Dengan menggunakan metode Diskusi Kelompok 
dengan materi biotik dan abiotik yang ingin dipelajari siswa tidak hanya melihat dan mendengar tapi lebih dari itu, siswa mampu melakukan kegiatan dan melihat sendiri yang sering mereka baca dan lihat pada buku pelajaran. Dengan melakukan kegiatan siswa menjadi tidak pasif serta materi mudah diingat selain itu belajar menjadi menyenangkan.

\section{DAFTAR PUSTAKA}

Ahmadi, Abu dan Joko Tri Prasetya. 2006. Strategi Belajar Mengajar. Penerbit Setia, Bandung.

A. Tabrani Rusyan, dkk, Pendekatan dalam Proses Belajar Mengajar, (Bandung: Remaja Karya)

Kemmis,S\&MC Taggart R.1988. The Action Research Planner. Victoria : Deakin University Press

Kartodirdjo.S.1993. Pendekatan Ilmu Alam dalam Metodologi. Jakarta : PT.Gramedia

Kasbollah, Kasihani.1999. Penelitian Tindakan Kelas untuk Guru Sains. Malang : RUT VI LIPI.

Milas, 1992. Metodologi Penelitian Pendidikan. Surabaya: SIC (Surabaya Intellectual Club).

Moleong, L,J.1994. Metodologi Penelitian Kuantitatif. Bandung : PT Remaja Rosdakarya

Notosusanto, N. 1985.Pembelajaran Ilmu Pengetahuan Alam. Jakarta : Balai Pustaka

Suryabrata, S.1992. Metodologi Penelitian. Jakarta : CV Rajawali

Winataputra, Udin, S, dkk. 2007. Teori Belajar dan Pembelajaran. Jakarta. Universitas Terbuka. 